\title{
THE EFFECT OF FIRM SIZE AND LEVERAGE ON VALUE OF THE FIRM (EMPIRICAL STUDY ON BUMN LISTED IN INDONESIAN STOCK EXCHANGE 2012 - 2017)
}

\author{
Novi Yanti ${ }^{1}$, Nova Begawati ${ }^{2}$ \\ 1,2Economic Faculty, Management Program, Ekasakti University \\ Email:dienqu955@gmail.com
}

\begin{abstract}
This study aims to determine affect of size and leverage on firm value of BUMN companies listed on the Stock Exchange in 2012-2017 either partially or simultaneously. The population in this study are all of BUMN companies listed on the Stock Exchange from 2012-2017, which amounted to 20 companies. The sample is in the form of selected BUMN company financial statements with certain criteria from 2012-2017. The analytical method used is multiple linear regression analysis and coefficient of determination. Hypothesis testing uses $t$ test and $F$ test. The results of multiple linear regression analysis indicate that firm size has a negative effect on firm value. Leverage has a positive effect on firm value. The results of the partial hypothesis test indicate that size has a significant effect on firm value while leverage does not have a significant effect on firm value. Simultaneously size and leverage have a significant effect on firm value. The contribution of size and leverage to company value is $43.8 \%$ and the remaining $56.2 \%$ is influenced by other variables.
\end{abstract}

Keywords: firm size, leverage, firm value.

\begin{abstract}
ABSTRAK
Penelitian ini bertujuan untuk mengetahui Apakah size dan leverage berpengaruh terhadap nilai perusahaan BUMN yang listed di BEI tahun 2012-2017 baik secara parsial maupun simultan. Populasi dalam penelitian ini adalah perusahaan BUMN yang listed di BEI dari tahun 2012-2017 yang berjumlah 20 perusahaan. Sampel berupa laporan keuangan perusahaan BUMN yang terpilih dengan kriterian tertentu dari tahun 2012-2017. Metode analisis yang digunakan adalah analisis regresi linier berganda dan koefisien determinasi. Uji hipotesis menggunakan uji t dan uji F. Hasil analisis regresi linier berganda menunjukkan bahwa ukuran perusahaan berpengaruh negatif terhadap nilai perusahaan. Leverage berpengaruh positif terhadap nilai perusahaan. Hasil uji hipotesis secara partial menunjukkan bahwa size berpengaruh signifikan terhadap nilai perusahaan sedangkan leverage tidak berpengaruh signifikan terhadap nilai perusahaan. Secara simultan size dan leverage berpengaruh signifikan terhadap nilai perusahaan. Adapun kontribusi size dan leverage terhadap nilai perusahaan adalah 43,8\% dan sisanya sebesar $56,2 \%$ dipengaruhi oleh variable lain.
\end{abstract}

Kata Kunci: ukuran perusahaan, leverage, nilai perusahaan.

\section{INTRODUCTION}

For the companies, improving financial performance is a must, so that the company's shares are attractive to investors. The establishment of a company has a clear goal the first goal of the company is to achieve maximum profit. The second objective of the company is to prosper the owner of the company or shareholders, while the third 
objective of the company is to maximize the value of the company reflected in its stock price (Mahendra, 2011).

High and low stock prices will reflect the value of the company. The high value of the company will make the market believe not only in the company's current performance but also in the company's prospects in the future (Hermuningsih, 2012). Investors will do an overview of a company by looking at financial ratios that reflect the high and low values of the company (Puspitasari, 2012).

Firm size and leverage are one of the factors that influence value the firm. Firm size is one indicator to see the development of a company since it was founded. The larger the company, the greater the operating activity and the risk to the company will be small because the size of the company can be seen from the size of the total asser that the company has and shows that large assets gain profits and stable growth of the company. According to Isbanah (2015: 231), The size of the company is a scale to be classified as large or small by the company according to various methods including: total assets and others. The bigger the company, the higher the interest of investors to invest their shares compared to small companies. According to Sulitiono (2010), large companies have stable profits compared to small companies because investors prefer companies that have stable profits.

Leverage is a ratio used to measure the extent to which assets are financed by debt (Kashmir, 2010). Leverage shows the ability of a company to fulfill all financial obligations of the company if the company is liquidated (Agnes, 2004). So leverage is a ratio that measures how much the company uses funding originating from debt (financial leverage) (Brigham et al, 2010). The use of higher leverage results in high fixed costs and the company must try to obtain EAT additions higher than its fixed costs. Debt reflects the ownership, agency and control of the company, the greater the debt or leverage will encourage the demand for increased returns for creditors and new owners.

Research doing by Gill and Obradovich (2012) which states that firm size has a positive and significant effect on firm value. Research by Cheng and Tzeng (2010) states that leverage has a positive effect on firm value and is supported by Maryadi et al. (2012). Similarly, the research conducted by Hermuningsih (2013) states that leverage has a positive and significant effect on firm value. Unlike Odongo, Leonard, and Mokoteli (2014) which states that leverage has a significant negative effect on firm value.

According to information obtained from www.voaindonesia.com, there are 18 BUMN listed as having poor performance. The number of BUMN companies that are performing poorly is also justified by Dahlan Iskan. Of the 141 BUMN in Indonesia there were 20 state-owned companies that succeeded in listing their companies on the Indonesia Stock Exchange until 2017. Weak performance and competitiveness of stateowned companies caused BUMN to compete less with other companies, therefore the need to implement Corporate Governance as a value and best practice which is fundamental for increasing the value of the firm (Rahadian, 2009). According to Pasaribu (2010) by going public, BUMN management is easier to monitor so that the transparency aspect becomes an absolute thing. This encourages transparency in the management of BUMN and improves company performance which has an impact on increasing the value of BUMN. below:

Based on the above, a conceptual framework can be made as shown in figure 1 


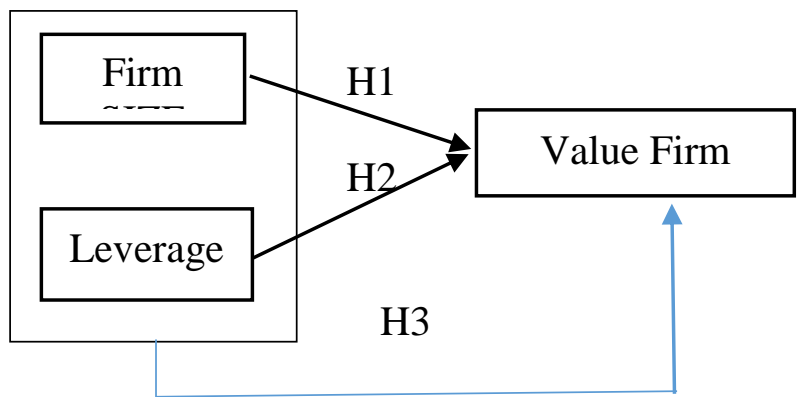

figure 1. conceptual framework

Based on Figure 1, the following hypotheses can be formulated:

"It is assumed that the size of the company and leverage have a significant effect on the value of the company both partially and simultaneously".

\section{RESEARCH METHODS}

This research was conducted on BUMN listed on the Indonesian capital stock exchange from 2012-2017. The data source used in this study is secondary data, that data taken from the BEI UNP outlets in the form of financial statements of BUMN that have been published. The data retrieval technique in this study is time series, namely data taken in a period of 6 years from 2012 - 2017. The analytical method used in this study is multiple linear regression analysis and coefficient of determination. Hypothesis testing is done by t test (partial) and $\mathrm{F}$ test (simultaneous) with 5 percent error tolerance. In this study using two independent variables namely firm size (TA) and leverage (DAR). The dependent variable is value firm (Tobins'q). The form of the multiple linear regression equation is as follows:

$$
\mathrm{Y}=\mathrm{a}+\mathrm{b} 1 \mathrm{X} 1+\mathrm{b} 2 \mathrm{X} 2+\mathrm{e}
$$

\section{RESULTS AND DISCUSSION}

In accordance with the formulation of the problem and hypothesis, the purpose of this research is to see the effect of company size and leverage on the value of stateowned companies listed on the Stock Exchange from 2012-2017. Before the multiple linear regression analysis is carried out, the analysis requirements test is done first, namely the classic assumption test using SPSS 19. The results of multiple linear regression analysis can be seen in table 1 .

\section{Table 1. Results of Multiple Linear Regression Analysis Coefficients ${ }^{\mathrm{a}}$}

\begin{tabular}{|c|c|c|c|c|c|c|}
\hline \multirow{2}{*}{\multicolumn{2}{|c|}{ Model }} & \multicolumn{2}{|c|}{ Unstandardized Coefficients } & \multirow{2}{*}{$\begin{array}{c}\text { Standardized } \\
\text { Coefficients }\end{array}$} & \multirow[b]{2}{*}{$\mathrm{t}$} & \multirow[b]{2}{*}{ Sig. } \\
\hline & & $\mathrm{B}$ & Std. Error & & & \\
\hline \multirow[t]{3}{*}{1} & (Constant) & $4.886 \mathrm{E} 6$ & 626701.765 & & 7.796 & .000 \\
\hline & SIZE & -299929.229 & 39644.304 & -.676 & -7.566 & .000 \\
\hline & DAR & 10466.194 & 17397.708 & .054 & .602 & .549 \\
\hline
\end{tabular}

a. Dependent Variable: NP 
follows:

Based on table 1, multiple linear regression equations can be made as

$$
\mathrm{Y}=4,886-299,929.22 \mathrm{X} 1+10.466,194 \mathrm{X} 2+\mathrm{e}
$$

The above equation can be interpreted: 1) Firm size variable (X1) has a coefficient that is negatively marked on value firm, 2) Constant value indicates the effect of variables $\mathrm{X}$ and $\mathrm{Y}$ (firm size and leverage). That is, if the size of the company and leverage equals zero, then the value of the firm is equal to a constant of 4,886 units; 3 ) the regression coefficient of firm size is -299.929 .22 , the meaning that if the number of company sizes rises by 1 unit, the value of the firm will decrease by 299,929.22 units assuming that the other variables in this study are constant; 4) The regression coefficient value of variable leverage is equal to $10.466,194$, meaning is if leverage increases 1 unit then the value of the company will increase by 10,466,194 units assuming that other variables are constant.

The results of the analysis of the coefficient of determination indicate the magnitude of the contribution of independent variables to the dependent variable. The results of the analysis can be seen in table 2 below.

Table 2. The results of the analysis of the coefficient of determination

\begin{tabular}{l|c|r|r|r|r|}
\hline & & & Model Summary & \\
Model & $\mathrm{R}$ & R Square & $\begin{array}{c}\text { Adjusted R } \\
\text { Square }\end{array}$ & $\begin{array}{c}\text { Std. Error of } \\
\text { the Estimate }\end{array}$ & $\begin{array}{c}\text { Durbin- } \\
\text { Watson }\end{array}$ \\
\hline 1 & $.673^{\mathrm{a}}$ & .453 & .438 & $5.0458942 \mathrm{E} 5$ & .720 \\
\hline
\end{tabular}
a. Predictors: (Constant), DAR, SIZE
b. Dependent Variable: NP

Based on table 2, the coefficient of determination is indicated by the adjusted $\mathrm{R}$ square value of 0.438 . This means that the contribution of size and leverage to the value of the firm is $43.8 \%$ while the remaining $56.2 \%$ is influenced by other variables such as profitability, CSR, GCG etc.

This research is supported by M. Saleh's research (2018) which states that company size has a negative and significant effect on firm value. This research is not supported with the research of Sulistiono (2010) which concluded that firm size has a positive and significant effect on firm value. Penelitian Rizqi Wahyu, dkk (2013) menyatakan bahwa ukuran perusahaan, profitabilitas berpengaruh secara signifikan terhadap variabel nilai perusahaan. Namun bertentangan dengan penelitian Angrita dan Winda (2016) yang menyatakan bahwa ukuran perusahaan tidak berpengaruh signifikan terhadap nilai perusahaan.

\section{Partial Hypothesis Test (t test) and Simultaneous Test (F test)}

Testing the partial effect aims to test whether each independent variable has a significant effect on the dependent variable partially with $\alpha=0.05$ and also the acceptance or rejection of the hypothesis. This partial test ( $t$ test) is used to see whether the independent variables, namely firm size (X1) and leverage (X2) partially influence the dependent variable, that is the firm value $(\mathrm{Y})$. Based on the results of data processing using SPSS 19, partial test results are obtained as follows:

Table 3. Parsial test (uji t)

\begin{tabular}{|l|l|c|c|c|}
\hline Model & Unstandardized Coefficients & $\begin{array}{c}\text { Standardized } \\
\text { Coefficients }\end{array}$ & $\mathrm{t}$ & $\mathrm{Sig}$. \\
\hline
\end{tabular}




\begin{tabular}{|rl|r|r|r|r|r|}
\hline & \multicolumn{1}{c|}{ B } & Std. Error & Beta & & \\
\hline 1 & (Constant) & $4.886 \mathrm{E} 6$ & 626701.765 & & 7.796 & .000 \\
& SIZE & -299929.229 & 39644.304 & -.676 & -7.566 & .000 \\
& & 10466.194 & 17397.708 & .054 & .602 & .549 \\
\hline
\end{tabular}

a. Dependent Variable: NP

Based on table 3, it can be explained as follows:

1. The value of the calculated variable size is $-7,566$ and a significance value of 0,000 . Significance value $<\alpha=0.05$, then Ha is accepted and Ho is rejected. This means that size (X1) has a significant effect on the firm value of BUMN listed on the IDX.

2. The value of the leverage variable is 0.602 and the significance value is 0.549 . Significance value $>\alpha=0.05$, then $\mathrm{Ha}$ is rejected and Ho is accepted. This means that leverage (X2) has no significant effect on the value of BUMN companies listed on the IDX.

To answer the hypothesis together a simultaneous test ( $\mathrm{F}$ test) is carried out. This $\mathrm{F}$ test is used to see whether the independent variables are size and leverage together on the dependent variable, which is the value of the firm. The results of calculation of F test statistics using SPSS can be seen in table 4 below:

Table 4. Simultaneous test (F test)

\begin{tabular}{|c|c|c|c|c|c|c|}
\hline \multicolumn{7}{|c|}{ ANOVA $^{b}$} \\
\hline \multicolumn{2}{|c|}{ Model } & $\begin{array}{c}\text { Sum of } \\
\text { Squares }\end{array}$ & Df & Mean Square & $\mathrm{F}$ & Sig. \\
\hline 1 & Regression & $1.458 \mathrm{E} 13$ & 2 & $7.289 \mathrm{E} 12$ & 28.626 & $.000^{\mathrm{a}}$ \\
\hline & Residual & $1.757 \mathrm{E} 13$ & 69 & $2.546 \mathrm{E} 11$ & & \\
\hline & Total & $3.215 \mathrm{E} 13$ & 71 & & & \\
\hline
\end{tabular}

a. Predictors: (Constant), DAR, SIZE

b. Dependent Variable: NP

3. From table 4, the calculated $F$ value is 28,626 and the significance is 0,000 . Significance value $<\alpha=0.05$, then $\mathrm{Ha}$ is accepted and Ho is rejected. This means that size and leverage together have a significant effect on the value of BUMN companies listed on the IDX.

\section{CONCLUSION}

The conclusions of this study are:

1. Company size has a negative and significant effect on company value. This is because the significance value is smaller than $\alpha$.

2. Leverage has a positive and not significant effect on firm value. This is because the significance value is greater than $\alpha$.

3. Firm size and leverage together have a significant effect. The size of the contribution of company size and leverage to the value of the company is $43.8 \%$ and the remaining $56.2 \%$ is influenced by other variables. 


\section{BIBLIOGRAPHY}

Agnes Sawir, 2004, Kebijakan Pendanaan dan Restrukturisasi Perusahaan, PT. Gramedia Pustaka Utama, Jakarta.

Angrita dan Denzi, 2016. Analisis Ukuran Perusahaan Dan Profitabilitas Terhadap Nilai Perusahaan (Studi Empiris Pada Perusahaan Yang Tergolong LQ45 di BEI Periode 2011-2014). Jurnal Akuntansi \& Keuangan Vol. 7, No. 2, September 2016 Halaman 241-254.

Brigham, E.F., dan Houston, J.F. 2010. Dasar-dasar Manajemen Keuangan. Jakarta: Salemba

Cheng, et al., 2010. "Capital Structure and Firm Value in China: A Panel Threshold Regression Analysis". African Journal of Business Management, Volume 4 (12), pp. 2500-2507.

Gill, Amarjit dan Obradovich, John. 2012. The Impact of Corporate Governance and Financial Leverage on the Value of American Firms. International Research Journal of Finance and Economics. ISSN 1450-2887 Issue 91

Hermuningsih, Sri. 2012. Pengaruh Profitabilitas, Size Terhadap Nilai Perusahaan Dengan Sruktur Modal Sebagai Variabel Intervening. Universitas Sarjanawiyata Tamansiswa Yogyakarta (2013). Pengaruh Profitabilitas, Growth Opportunity, Sruktur Modal Terhadap Nilai Perusahaan Pada Perusahaan Publik di Indonesia. Buletin Ekonomi Moneter dan Perbankan, Oktober 2013, 128.

Isbanah, Yuyun. 2015. Pengaruh ESOP, Leverage, dan Ukuran Perusahaan Terhadap Kinerja Keuangan Perusahaan Di Bursa Efek Indonesia. Journal Of Research In Economics And Management. Universitas Negeri Surabaya. Vol. 15, No. 1.

Kasmir, 2010. Pengantar Manajemen Keuangan. Jakarta: Kencana Prenada Media Group.

Kodongo, Odongo, Thabang Mokoaleli-Mokoteli, and Leonard Maina. 2014. Capital Structure, Profitability and Firm Value: Panel Evidence of Listed Firms in Kenya. Munich Personal RePEc Archive. No 57116.

Mahendra, Alfredo DJ. 2011. Pengaruh Kinerja Keuangan Terhadap Nilai Perusahaan (Kebijakan Deviden Sebagai Variabel Moderating) Pada Perusahaan Manufaktur Di Bursa Efek Indonesia. Tesis Pascasarjana Universitas Udayana Denpasar

M. Saleh Eldi Putra, 2018. Pengaruh ukuran perusahaan dan leverage terhadap nilai perusahaan dengan dimediasi profitabilitas pada perusahaan yang terdaftar di Jakarta Islamic index. Skripsi Fakultas Ekonomi dan Bisnis Islam, UIN Raden Fatah.

R. indah Puspitasari, 2012. "Pengaruh Kinerja Keuangan terhadap Nilai Perusahaan Dengan Pengungkapan Corporate Social Responsibility Dan Good Corporate Governance sebagai Variabel Pemoderasi," J. Progr. Stud. Akunt. Fak. Ekon. Univ. Siliwangi Tasikmalaya.

Rizqi Wahyu, dkk, 2013. Analisis Faktor Mikro Terhadap Struktur Modal Dan Nilai Perusahaan (Studi Pada Perusahaan Non-Bank Yang Terdaftar Di Bursa Efek Indonesia Indeks LQ 45 Periode 2009-2011). Jurnal Administrasi Bisnis (JAB) Vol. 2 No.1 Mei 2013

Sulistiono. 2010. Pengaruh Kepemilikan Manjerial, Struktur Modal Dan Ukuran Perusahaan Terhadap Nilai Perusahaan pada Perusahaan Manufaktur di BEI. Skripsi. Universitas Negeri Semarang. Semarang 
International Conference on Glo6alEducation VII

"Humanising Technology For IR. 4.0"

U. Sekaran, 2011. Research Methods For Business (Metodologi Penelitian Bisnis). Jakarta: Salemba Empat. 